\title{
KAJIAN SEBARAN PRODUKTIVITAS PADI SAWAH MENGGUNAKAN DATA CITRA LANDSAT 8 DI DAERAH IRIGASI BATANG ANAI KABUPATEN PADANG PARIAMAN
}

\author{
Rijal Budiman ${ }^{1}$, Eri Gas Ekaputra ${ }^{2}$, dan Isril Berd ${ }^{2}$ \\ ${ }^{1}$ Mahasiswa Program Magister Teknik Pertanian dan Biosistem, Universitas Andalas \\ ${ }^{2}$ Dosen Fakultas Teknologi Pertanian, Universitas Andalas \\ Email: budimanrijal91@gmail.com
}

\begin{abstract}
ABSTRAK
Irigasi skala besar pada umumnya memiliki ketersediaan air cenderung tidak merata dari hulu, tengah dan hilir, sehingga mempengaruhi akan produktivitas tanaman padi. Daerah Irigasi Batang Anai merupakan irigasi skala besar dengan luas daerah layanan 13.604 ha tentu membutuhkan waktu, tenaga dan biaya yang tinggi untuk melakukan perhitungan produktivitas secara manual. Salah satu teknologi yang dimanfaatkan untuk mendukung perhitungan produktivitas padi adalah dengan memanfaatkan algoritma nilai Normalized Difference Vegetation Indeks (NDVI) dari analisis citra Landsat 8 selama 6 tahunan. Melalui identifikasi umur tanaman padi dapat diketahui pola tanam dan waktu panen. Nilai NDVI pada saat akan panen atau padi berumur 14-16 MST dijadikan acuan untuk pendugaan produktivitas yang dikorelasikan dengan produktivitas data ubinan. Analisis pada umur 14-16 MST didapatkan hubungan negatif. Semakin tinggi nilai NDVI maka produktivitas semakin rendah dengan nilai koefisien determinasi $\left(\mathrm{R}^{2}\right)$ adalah 0,8856 . Dengan persamaan regresi yang didapatkan $\mathrm{y}=-9,4514 \mathrm{x}+10,467$. Terdapat nilai simpangan tertinggi $10,86 \%$ atau 0,61 ton, sedangkan yang terkecil yaitu $1,45 \%$ atau 0,07 ton. Sebaran produktivitas padi berdasarkan nilai NDVI di Daerah Irigasi Batang Anai dibagi menjadi tiga kawasan yaitu hulu sebesar 6,45 ton/ha GKP, tengah sebesar 6,46 ton/ha GKP, dan hilir sebesar 5,42 ton/ha GKP.

Kata kunci - produktivitas; ubinan; remote sensing; landsat 8; dan algoritma NDVI
\end{abstract}

\section{PENDAHULUAN}

Sumatera Barat merupakan kawasan pertanian baik pada daerah perbukitan maupun daerah dataran. Kawasan pertanian tersebut tak lepas dari keberadaan sumber daya air untuk pemenuhan kebutuhan lahan tersebut khususnya padi sawah yang biasanya dialiri oleh beragam irigasi baik irigasi berskala kecil maupun irigasi berskala besar. Pada daerah irigasi berskala besar produktivitas padi sangatlah beragam karena disuatu daerah tidak sama ketersediaan airnya. Pada kasus seperti ini kecenderungan distribusi air daerah hilir akan lebih sedikit dibandingkan pada daerah tengah apalagi pada daerah hulu. Upaya memenuhi ketahanan pangan Sumatera Barat maka dukungan daerah irigasi ini sangat dibutuhkan terutama jaminan air untuk memenuhi kebutuhan air tanaman. Irigasi skala besar sangat dipengaruhi oleh ketersediaan airnya terutama pada daerah hilir, daerah hilir akan memiliki ketersedian air lebih sedikit dibanding dengan kawasan hulu. Sehingga mengakibatkan produktivitas tidak merata dan tidak bisa ditanami secara serentak.

Produksi Padi Sumatera Barat pada tahun 2018 sebanyak 1.509.337 Ton sedangkan Kabupaten Padang Pariaman sebanyak 146.016 Ton yang mana Daerah Irigasi Batang Anai adalah salah satu penghasil padi terbesar di kabupaten Pariaman dengan daerah layanan 13.604 Ha. Daerah Irigasi Batang Anai yang luas tentunya membutuhkan waktu yang lama bila dilakukan perhitungan produktivitas secara konvensional dan rendahnya efisiensi dalam mempresentasikan data. Untuk itu diperlukan sarana pengumpul data dan informasi sistem produksi pertanian yang lebih akurat dalam waktu secepat mungkin yaitu dengan memanfaatkan teknologi penginderaan jauh. Teknologi Pengindraan jauh (remote sensing) sudah berkembang pesat dan pengaplikasiannya semakin luas untuk berbagai bidang, salah satunya pada sektor pertanian. Perekaman atau pengumpulan data penginderaan jauh dapat dilakukan dengan menggunakan sensor yang dipasang pada pesawat terbang atau satelit (Lillesand dan Kiefer, 1979).

Untuk menentukan umur tanaman dan produktivitas padi sawah diperlukan data pendukung yang akurat, cepat dan mudah didapatkan, dengan memanfaatkan parameter tingkat kehijauan tanaman atau Algoritma dari nilai Normalized Difference Vegetation Indeks (NDVI) dari citra 
Landsat 8 , dengan mengidentifikasi fenologi tanaman. Penelitian ini bertujuan untuk mendapatkan sebaran produktivitas tanaman padi di daerah irigasi Batang Anai berdasarkan analisis Citra Lansat 8 dengan memanfaatkan Algoritma nilai NDVI.

\section{A. Waktu dan Tempat}

\section{METODOLOGI PENELITIAN}

Penelitian dilaksanakan mulai dari bulan Mei 2020 sampai dengan bulan Juni 2020. Penelitian ini dilakukan di Daerah Irigasi Batang Anai Kabupaten Padang Pariaman, antara lain; Kecamatan (Lubuk Alung, Batang Anai, Sintuk Toboh Gadang dan Ulakan Tapakis). dan dianalisis di Laboratorium Teknik Sumberdaya Air dan Lahan Pertanian Jurusan Teknik Pertanian Universitas Andalas Padang.

\section{B. Bahan dan Alat}

Alat yang digunakan dalam penelitian ini adalah perangkat keras berupa seperangkat komputer, perangkat lunak seperti; ArcGis 10.5, Global Mapper 12 dan Microsoft Office. Global Positioning System (GPS), Digital Camera dan penyimpan data (hardisk eksternal). Bahan yang dibutuhkan dalam pelaksanaan penelitian ini terdiri dari: (1) data Citra Landsat 8 Operation Land Imager (OLI)/Thermal Infra Red Sensor (TIRS) tahun 2014-2019, (2) data Rencana Tata Ruang Wilayah (RTRW) Kabupaten Padang Pariaman, (3) data Pertanian Lahan Basah (sawah eksisting), (4) data Daerah irigasi (DI), Data BPS Kabupaten Padang Pariaman dan (5) data klimatologi.

\section{Pelaksanaan Penelitian}

Penelitian ini dilakukan beberapa tahapan yaitu; (1) pengumpulan data, (2) pengolahan data, (3) pengolahan data spasial (4) pendugaan produktivitas padi sawah. Sistematika pelaksanaan penelitian dapat dilihat pada diagram alir pada Gambar 1.

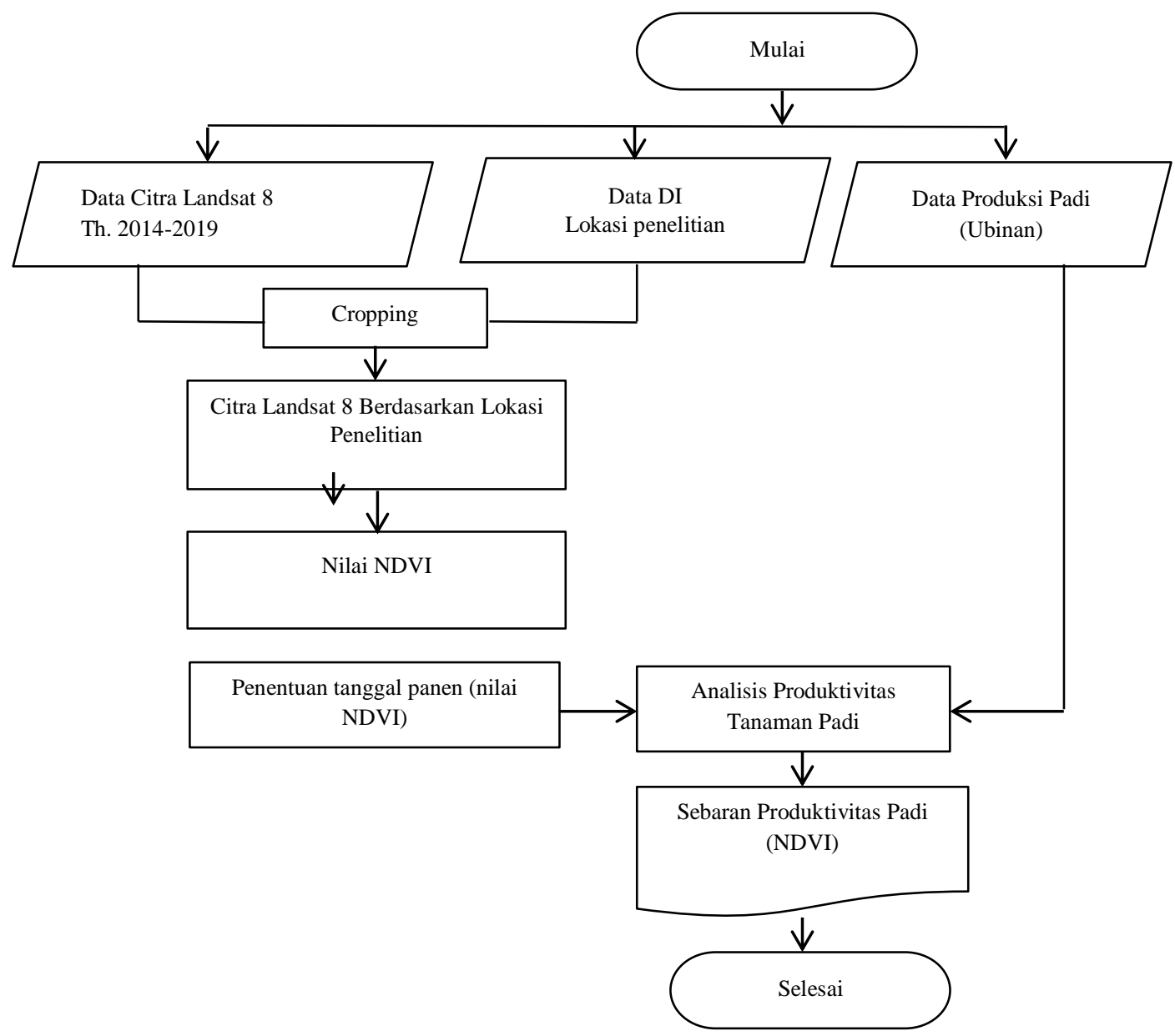

Gambar 1. Alur Penelitian 


\section{Pengolahan Data Spasial}

Tahapan pengolahan data terdiri dari beberapa proses yaitu: (1) cropping lokasi penelitian, 2) koreksi geometrik dan koreksi radiometrik, (3) analisis Normalized Difference Vegetation Indeks (NDVI). Untuk mengetahui nilai reflektan band digunakan persamaan (1) dan perhitungan koreksi atmosfer digunakan persamaan (2) (USGS, 2019).

$\rho \lambda^{\prime}=\mathrm{M}_{\rho} \times \mathrm{Q}_{\mathrm{cal}}+\mathrm{A}_{\rho}$

keterangan :

$\rho \lambda^{\prime} \quad=$ Spectral Reflectance;

$\mathrm{M}_{\rho} \quad$ = faktor skala multiplikasi reflektan pada band;

$\mathrm{A}_{\rho} \quad=$ faktor skala aditif reflektan pada band; dan

$\mathrm{Q}_{\mathrm{cal}} \quad=$ nilai digital number .

$\rho \lambda=\frac{\rho \lambda^{\prime}}{\cos (\theta S Z)}=\frac{\rho \lambda^{\prime}}{\sin (\theta S E)}$

keterangan :

$\rho \lambda \quad=$ Top of Atmosphere Reflectance;

$\theta_{\mathrm{SE}} \quad=$ sudut ketinggian matahari lokal; dan

$\theta_{\mathrm{SZ}} \quad=$ sudut zenith matahari lokal, $\left(\theta_{\mathrm{SZ}}=90^{\circ}-\theta_{\mathrm{SE}}\right)$

Upaya untuk mengkarakterisasi tahap-tahap fenologi padi sawah dengan menggunakan indeks vegetasi NDVI dihitung menggunakan persamaan (3) (Lonita et al., 2015).

$\mathrm{NDVI}=\frac{\rho \text { NIR }-\rho \text { red }}{\rho \text { NIR }+\rho \text { red }}$

keterangan :

NDVI = Normalized Difference Vegetation Indeks;

$\rho N I R=$ reflaktansi permukaan kanal NIR; dan

pred $=$ reflaktansi permukaan kanal merah.

Data reflektansi permukaan dioleh menjadi NDVI untuk keperluan tahap-tahap fenologi padi sawah dikarakterisasi melalui 3 tahap (i) Tahap penanganan/inundasi atau penanaman padi (ii) tahap heading (puncak tahap vegetatif dan generatif ditandai dengan keluarnya bunga/malai) dan (iii) Tahap pematangan bulir. Pada tahap akan panen nilai NDVI dihubungkan dengan produktivitas data ubinan, pada beberapa titik ground truth (tinjau lapangan) yang mewakili sebaran lahan sawah di Daerah Irigasi Batang Anai.

\section{Produktivitas Padi Ubinan}

Perhitungan produktivitas tanaman padi dihitung setiap sampel ubinan yang tersebar di beberapa lokasi hulu, tengah dann hilir pada daerah irigasi Batang Anai. Sistem perhitungan Ubinan dilakukan dengan sistem Tegel (2,5 x 2,5) $\mathrm{m}$ (BBPTP, 2017), dihitung dengan persamaan (4):

GKP $($ Ton/ha) $=$ U x 16

$\operatorname{GKP}(\mathrm{kg} / \mathrm{ha})=\left(\right.$ nilai ubinan $\mathrm{x}\left(10.000 \mathrm{~m}^{2}:(2,5 \mathrm{~m} \mathrm{x} 2,5 \mathrm{~m})\right)$

keterangan:

$$
\begin{aligned}
& =(U \times(10.000: 6,25) \\
& =(U \times 1.600) \mathrm{kg} / \mathrm{ha}
\end{aligned}
$$

GKP = gabah kering panen (ton/ha)

$\mathrm{U} \quad=$ nilai ubinan $(\mathrm{kg})$

\section{Sebaran Produktivitas Tanaman Padi}

Perhitungan produksi padi dengan metode ubinan dilakukan seperti yang dilakukan oleh badan pusat statistik (BPS) dan dinas Pertanian dan ketahanan pangan. Untuk mengetahui produktivitas padi (kg/ubinan) kemudian ditransformasikan kedalam satuan ton/ha. Untuk melengkapi jumlah contoh produktivitas hasil ubinan digunakan juga catatan hasil ubinan yang dilakukan para mantri tani, mantri statistik lapangan yang disesuaikan dengan waktu perekaman citra satelit. Faktor yang mempengaruhi kondisi lahan seperti; tanah, ketersediaan air dan manageman dianggap telah 
mencerminkan dalam tingkat kehijauan tanaman yang diukur dengan nilai NDVI. Dengan demikinan kisaran nilai NDVI yang sama pada wilayah berbeda diharapkan akan mempunyai kisaran hasil/produksi sama pula. Model regresi linier digunakan dengan metode pendugaan Ordinary least Square (OLS), dengan formula:

Produktivitas $(\mathrm{t} / \mathrm{ha})=\mathrm{a}(\mathrm{NDVI})+\mathrm{b}$

Dari persamaan tersebut diperoleh koefisien deteminasi $\left(\mathrm{R}^{2}\right)$ yang menerangkan keeratan korelasi antara produktivitas padi dengan nilai NDVI. model estimasi ini digunakan sebagai dasar/acuan dalam estimasi produktivitas padi yang mempunyai kondisi (ekosistem) yang serupa dengan lokasi sampel Penelitian. Sebagai langkah validasi model tersebut diaplikasikan di beberapa lokasi lain pada DI. Angka pendugaan produktivitas menggunakan model validasi dengan hasil lapangan pada beberapa lokasi, sehingga dapat diperkirakan besarnya penyimpangan angka produktivitas hasil pendugaan dan kondisi sebenarnya dilapangan.

\section{HASIL DAN PEMBAHASAN}

\section{A. Kondisi Daerah Irigasi Batang Anai}

Daerah Irigasi Batang Anai merupakan suatu kawasan yang berada di Kabupaten Padang Pariaman, Provinsi Sumatera Barat dengan luas daerah layanan 13604 Ha dengan luas sawah 6.926 Ha (PSDA Sumatera Barat). Secara astronomis Daerah Irigasi Batang Anai terletak antara $100^{\circ} 07^{\prime}$ 00' bujur timur dan $0^{\circ} 36^{\prime} 00^{\prime}$ lintang selatan. Daerah Irigasi ini terletak di lima Kecamatan, yaitu ; Kecamatan Lubuk Alung; Kecamatan Nan Sabaris; Kecamatan Batang Anai: Sintok Toboh Gadang dan Kecamatan Ulakan Tapakis, Daerah Irigasi Batang Anai seperti (Gambar 2).

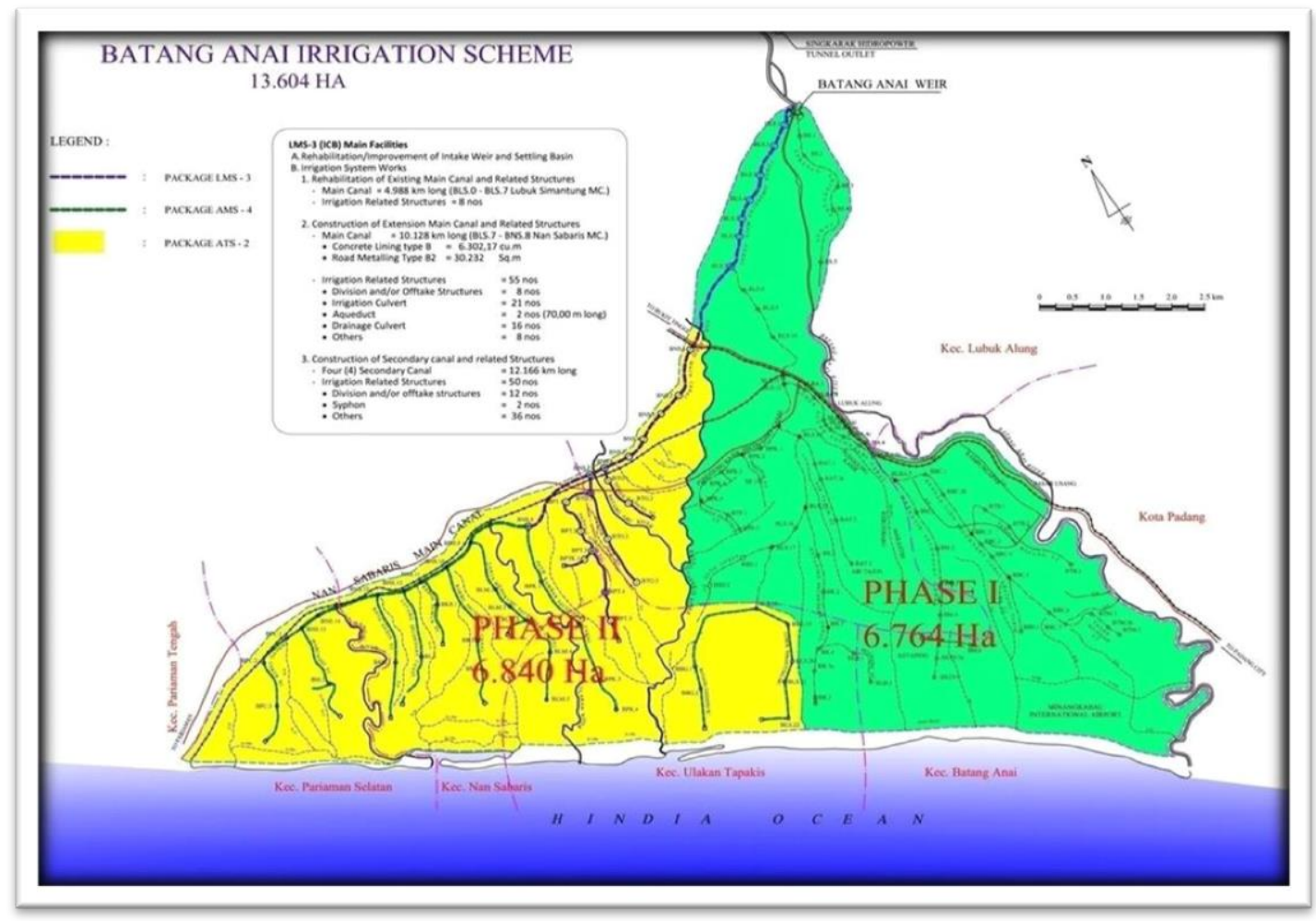

Gambar 2. Daerah Irigasi Batang Anai

\section{B. Hubungan Nilai Algoritma NDVI dengan umur Tanaman Padi}

Tingkat kehijauan tanaman diperkirakan melalui analisis data digital citra satelit menggunakan formula NDVI (Normalized Difference Vegetation Index), dihitung secara otomatis menggunakan ArcGis. Wahyunto et al., (2006) menyatakan bahwa nilai algoritma NDVI berkisar antara -1 hingga +1 , dimana nilai (-) menunjukkan objek air atau lahan bera dan basah dan nilai (+) menunjukkan objek vegetasi. Untuk tanaman padi sawah, NDVI baru dapat diukur setelah tanaman padi mencapai 
umur 3-4 MST (Minggu Setelah Tanam), karena sebelum umur tersebut kenampakan tanaman padi di lahan sawah masih didominasi kenampakan genangan air (Malingreau, 1981). Hubungan nilai NDVI terhadap tingkat pertumbuhan tanaman padi pada lokasi penelitian dapat dilihat pada Tabel 1.

Tabel 1. Hubungan Nilai NDVI terhadap Pertumbuhan Tanaman Padi

\begin{tabular}{ccccc}
\hline No & \multicolumn{2}{c}{ Rentang NDVI } & Tingkat Kehijauan & Umur Tanam (MST) \\
\hline 1 & 0.0169 & 0.1354 & Tidak bervegetasi/Terbuka/Air & $<3$ \\
2 & 0.1354 & 0.2540 & Kehijauan sangat rendah & $3-6$ \\
3 & 0.2540 & 0.3725 & Kehijauan rendah & $6-8$ \\
4 & 0.3725 & 0.4910 & Kehijauan sedang & $8-10$ \\
5 & 0.4910 & 0.6095 & Kehijauan tinggi & $10-13$ \\
\hline
\end{tabular}

Setelah vegetatif optimum nilai NDVI akan turun sesuai dengan tingkat kematangan bulir padi Sumber : Hasil interpretasi citra Landsat 8

Hasil interpretasi citra satelit Landsat 8 selama 6 tahun yaitu diperoleh pada rentang minimum pada angka 0.0169 dan maksimum pada angka 0,6095. Rentang nilai NDVI terbagi menjadi 5 kategori hingga mencapai titik tingkatan kehijauan maksimum yaitu tidak bervegetasi/terbuka/air, kehijauan sangat rendah, kehijauan rendah, kehijauan sedang dan kehijauan tinggi, sesuai dengan kondisi umur tanaman dalam satuan Minggu Setelah Tanam (MST). Nilai minimum diartikan kondisi tidak bervegetasi, atau lahan terbuka maupun berupa permukaan air yang diperkirakan padi sekitar kecil dari 3 minggu. Sedangkan nilai maksimum menggambarkan kondisi permukaan dengan tingkat kehijauan tinggi yakni sekitar umur 10-13 minggu setelah tanam, pada tahap ini vegetasi padi berada pada akhir fase vegetatif dan masuk pada fase pematangan bulir.

Umur tanaman padi rata-rata berkisar antara 110-120 hari jika dihubungkan dengan Nilai NDVI saat tanaman padi berumur 3 MST sampai dengan 16 MST, menunjukan bentuk kurva parabolik yaitu saat padi berada pada fase vegetatif optimum - padi bunting (umur sekitar 70-80 hari atau 10-13 MST). Kemudian nilai NDVI akan turun kembali pada fase pengisian bulir, pematangan sampai panen (berumur sekitar 14-16 MST). Berdasarkan hal tersebut maka nilai NDVI dapat digunakan untuk menentukan perkiraan panen, tergantung pada varietas padi yang ditanam. Wahyunto et al., (2006) menyatakan bahwa setelah vegetatif optimum nilai indeks vegetasi akan turun sesuai dengan tingkat kematangan bulir padi.

\section{Pendugaan Produktivitas Tanaman Padi Sawah}

Nilai produktivitas tanaman padi diperoleh dari pengolahan data ubinan hasil survei lapangan (tersedia di BPS kabupaten padang Pariaman). Nilai ubinan merupakan berat total padi hasil panen atau sampel seluas 2,5 x 2,5 meter, lalu sampel padi yang telah diukur tersebut dipotong, dirontokkan, dan ditimbang kemudian dikonversi dalam satuan ha. Pehitungan Produktivitas dihitung berdasarkan persamaan (4). Berikut merupakan tabel hasil Produktivitas ubinan yang didapatkan BPS pada 10 sampel lokasi di lapangan dapat dilihat pada Tabel 2.

Tabel 2. Hubungan nilai NDVI dan Perhitungan Produktivitas ubinan

\begin{tabular}{cccc}
\hline No & $\begin{array}{c}\text { Nilai NDVI } \\
\text { (umur 14-16 MST) }\end{array}$ & Nilai Ubinan $(\mathrm{kg})$ & $\begin{array}{c}\text { Produktivitas Ubinan } \\
\text { (ton/ha) }\end{array}$ \\
\hline 1 & 0,226537 & 5,19 & 8,30 \\
2 & 0,498947 & 3,65 & 5,84 \\
3 & 0,416079 & 3,75 & 6,00 \\
4 & 0,267007 & 4,88 & 7,80 \\
5 & 0,384113 & 4,62 & 7,39 \\
6 & 0,503193 & 3,38 & 5,40 \\
7 & 0,400996 & 4,06 & 6,50 \\
8 & 0,461259 & 4,23 & 6,77 \\
9 & 0,581255 & 3,03 & 4,84 \\
10 & 0,450282 & 3,89 & 6,23 \\
\hline
\end{tabular}

Sumber: Analisis Data dan BPS (data individu) 
Berdasarkan Tabel 2, dari 10 titik sampel yang diambil nilai produktivitas ubinan tertinggi yaitu 8,30 ton/ha dengan nilai NDVI 0,226537 berada pada titik no. 1 , sedangkan produktivitas ubinan terendah yaitu 4,84 ton/ha dengan nilai NDVI 0,581255 berada pada titik no.9. Data produktivitas ubinan yang dihubungkan dengan nilai NDVI berdasarkan analisis dari citra lansat 8 memiliki hubungan negatif karena semakin besar nilai NDVI semakin rendah produktivitas yang di dapatkan. Untuk melihat hubungan nilai NDVI dengan Produktivitas berdasarkan ubinan dapat dilihat pada gambar 3 sebagai berikut:

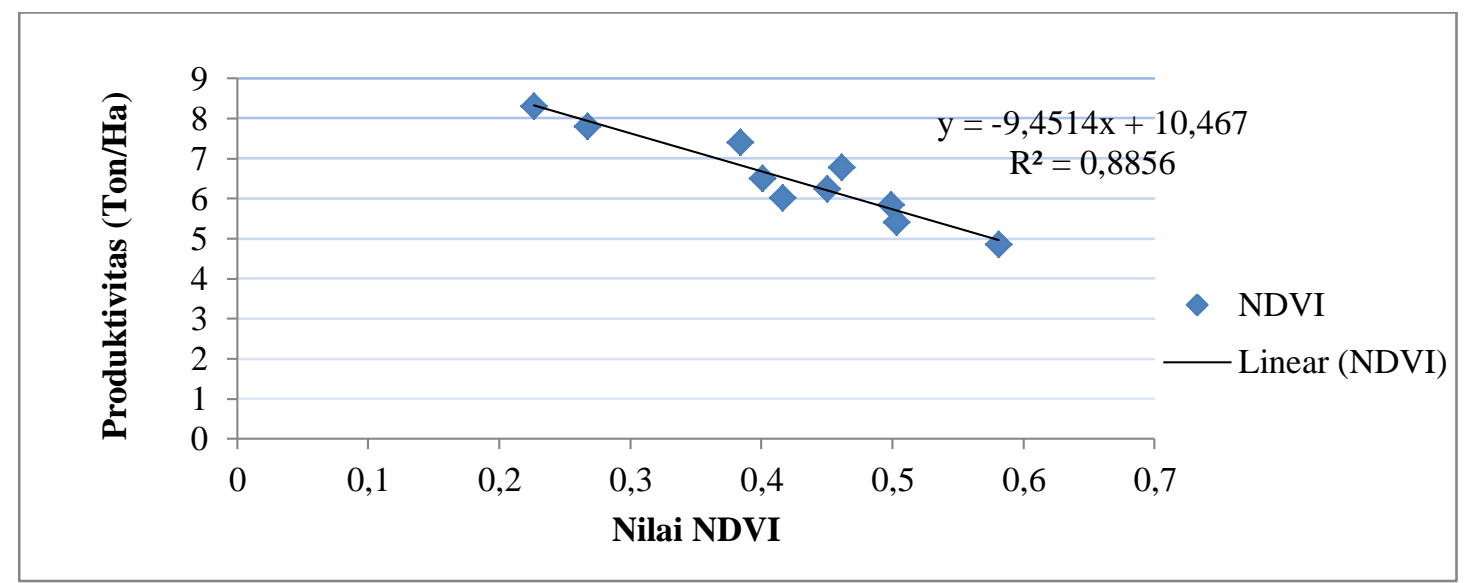

Gambar 3. Hubungan Tingkat Kehijauan Tanaman (nilai NDVI) dengan Produktivitas Tanaman Padi Sawah

Analisis untuk memperoleh nilai NDVI tanaman padi adalah rekaman citra satelit pada saat pada fase generatif (pematangan bulir) saat padi berumur sekitar 14-16 MST atau umur padi 110-120 hari, dimana pada fase ini tanaman padi dominan berwarna kuning. Data pada Tabel 2 dan Gambar 3 di atas bahwa hubungan nilai NDVI dengan produktivitas tanaman padi mempunyai hubungan negatif artinya semakin tinggi nilai NDVI maka produktivitas semakin rendah, didapatkan nilai koefisien determinasi $\left(\mathrm{R}^{2}\right)$ adalah 0,8856 , dengan persamaan regresi yang didapatkan $\mathrm{y}=-9,4514 \mathrm{x}+10,467$ artinya konstanta $\mathrm{a}=-9,4514$ dan $\mathrm{b}=10,467$. Penelitian yang dilakukan oleh Wahyunto et al., (2006) menyatakan bahwa nilai NDVI dengan produktivitas tanaman padi umumnya mempunyai hubungan positif artinya kenaikan nilai NDVI akan diikuti oleh meningkatnya nilai Produktivitas tanaman padi. Perbedaan hasil penelitian ini disebabkan analisis yang dilakukan oleh penelitian sebelumnya melakukan pengamatan nilai NDVI pada fase tanaman padi berumur sekitar 10 - 12 MST yaitu pada fase puncak parabolik yaitu vegetatif optimum, sedangkan pada penelitian ini pengamatan nilai NDVI dilakukan pada fase generatif yaitu pada saat padi akan panen yang mana nilai NDVI akan turun setelah puncak parabolik yaitu pada saat padi berumur 14-16 MST atau 110-120 hari.

Persamaan yang didapatkan diatas akan dikalkulasikan untuk menentukan sebaran produktivitas padi sawah di daerah irigasi Batang Anai berdasarkan nilai NDVI. Validasi hasil persamaan yang didapatkan dilakukan pada beberapa titik lokasi, dapat dilihat pada Tabel 3.

Tabel 3. Data Sampel Ubinan untuk Validasi

\begin{tabular}{cccc}
\hline No. Sampel & Kawasan & Nilai Ubinan $(\mathrm{Kg})$ & Ton/ha GKP \\
\hline 1 & & 5,00 & 8,0 \\
2 & \multirow{2}{*}{ Hulu } & 4,88 & 7,8 \\
3 & & 3,50 & 5,6 \\
4 & & 4,06 & 6,5 \\
\hline 5 & \multirow{3}{*}{ Tengah } & 5,00 & 8,0 \\
6 & & 3,00 & 4,8 \\
7 & & 4,50 & 7,2 \\
\hline 8 & \multirow{2}{*}{ Hilir } & 3,00 & 4,8 \\
9 & & 3,13 & 5,0 \\
10 & & 4,69 & 7,5 \\
\hline
\end{tabular}

Sumber: BPS Padang Pariaman 
Nilai ubinan tertinggi adalah 5,00 kg pada titik sampel pertama dan kelima sedangkan nilai terendah pada titik sampel keenam dan kedelapan dengan hasil 3,00 $\mathrm{kg}$, dengan varietas padi yang pada umumnya ditanam oleh petani adalah jenis IR42. Nilai ubinan berbeda dikarenakan masing lokasi memiliki tingkat kesuburan tanah yang berbeda-beda.

Berdasarkan Tabel 3, dapat diketahui bahwa produktivitas tanaman padi kawasan hulu lebih tinggi di banding kawasan tengah dan kawasan hilir. Hal ini dikarenakan katersediaan air pada masing kawasan berbeda-beda, karena kecendrungan kawasan hulu memiliki ketersediaan air yang melimpah dan tingkat kesuburan tanah yang berbeda. Perbandingan produktivitas bedasarkan NDVI dengan produktivitas berdasarkan hasil ubinan di lapangan (BPS) dapat dilihat pada Tabel 4.

Tabel 4. Perbandingan Produktivitas Tanaman Padi

\begin{tabular}{cccccc}
\hline No & Kawasan & $\begin{array}{c}\text { Produktivitas } \\
\text { (Ton/ha) (BPS) }\end{array}$ & $\begin{array}{c}\text { Produktivitas } \\
\text { (ton/ha) (NDVI) }\end{array}$ & $\begin{array}{c}\text { Simpangan } \\
\text { (ton) }\end{array}$ & Persentase (\%) \\
\hline 1 & & 8,0 & 7,3 & 0,74 & 9,30 \\
2 & \multirow{2}{*}{ Hulu } & 7,8 & 7,3 & 0,46 & 5,95 \\
3 & & 5,6 & 5,0 & 0,61 & 10,86 \\
4 & & 6,5 & 6,2 & 0,27 & 4,20 \\
\hline & Rata-rata & 6,98 & 6,45 & 0,52 & 7,58 \\
\hline 5 & & 8,0 & 7,7 & 0,29 & 3,62 \\
6 & \multirow{2}{*}{ Tengah } & 4,8 & 4,7 & 0,07 & 1,45 \\
7 & & 7,2 & 6,9 & 0,26 & 3,56 \\
\hline & Rata-rata & 6,67 & 6,46 & 0,20 & 2,87 \\
\hline 8 & \multirow{2}{*}{ Hilir } & 4,8 & 4,3 & 0,50 & 10,33 \\
9 & 5,0 & 4,7 & 0,32 & 6,40 \\
10 & & 7,5 & 7,3 & 0,22 & 2,97 \\
\hline & Rata-rata & 5,77 & 5,42 & 0,35 & 6,57 \\
\hline
\end{tabular}

Sumber: Analisis data

Berdasarakan Tabel 4, dapat diketahui bahwa pendugaan produktivitas tanaman Ppdi hasil analisis citra satelit berdasarkan nilai NDVI mendapatkan hasil yang lebih kecil dibandingkan dengan hasil ubinan (BPS). Penyimpangan hasil berkisar antara 0,07 sampai 0,74 Ton/ha atau 1,45-10,86\% per Ha. Terdapat nilai simpangan tertinggi pada lokasi hulu pada sampel nomor 3 sebesar 10,86\% sedangkan yang terkecil terdapat pada sampel nomor 6 yaitu sebesar 1,45\%, berdasarkan nilai ratarata per kawasan pada daerah hulu didapatkan nilai simpangan 6,5\%, pada kawasan tengah 3,6\% dan pada kawasan hilir terdapat pengyimpangan data sekitar 5,1\%. Perbedaan ini disebabkan karena hasil ubinan yang dilakukan oleh mantra tani atau mantra statistik cenderung pada tanaman padi yang relative baik pertumbuhannya (diatas rata-rata) (Wahyunto dkk, 2006). Namum dilihat dari persentase perbandingan nilai simpangan yang tidak terlalu tinggi, artinya perhitungan produktivitas tanaman padi berdasarkan nilai NDVI di daerah Irigasi Batang Anai mendekati kebenaran.

\section{KESIMPULAN}

Sebaran Produktivitas berdasarkan nilai NDVI tanaman padi di Daerah Irigasi Batang Anai dibagi menjadi tiga kawasan yaitu hulu, tengah, dan hilir. Produktivitas tanaman padi di hulu sebesar 6,45 ton/ha GKP, lebih kecil dibanding kawasan tengah yaitu sebesar 6,46 ton/ha GKP, namun tak jauh berbeda sedangkan pada kawasan hilir jauh lebih kecil yaitu sebesar 5,42 ton/ha GKP.

\section{DAFTAR PUSTAKA}

[PSDA] Pengelolaan Sumber Daya Air. 2019. Luas Daerah Irigasi Batang Anai. Padang: Dinas Pengelolaan Sumber Daya Air Provinsi Sumatera Barat.

[BBPTP] Balai Besar Penelitian Tanaman Padi. 2017. Teknik Ubinan Pendugaan Produktivitas Tanaman Padi menurut sistem tanam. http://pangan.litbang.pertanian.go.id/files/teknikubinan-pendugaan-produktivitas-padi-menurut-sistem-tanam.pdf. 
Lillesand T.M. dan Kiefer R.W. 1979. Remote Sensing and Image Interpretation. Numerous Illustrations. New York: John Wiley. 612 hal.

Lonita B.I, Prasetyo Y. dan Hani'ah. 2015. Analisis Perubahan Luas dan Kerapatan Hutan menggunakan Algoritma NDVI dan EVI pada Citra Landsat 7. Jurnal Geodesi. Universitas

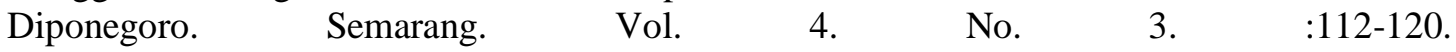
https://ejournal3.undip.ac.id/index.php/geodesi/article/view/8965

U. S. Geological Survey. 2019. Landsat 8 (L8) Data Users Handbook. Version 5.0. Department of the Interior U.S. Geological Survey. EROS. Sioux Falls. South Dakota. 114 hal.

Wahyunto, Widagdo dan Heryanto B. 2006. Pendugaan Produktivitas Tanaman Padi Sawah melalui Analisis Citra Satelit. Informatika Pertanian. Bogor: Balai Besar Penelitian dan Pengembangan Sumberdaya Lahan Pertanian. Vol. 15. : 853-869. http://www.litbang.pertanian.go.id/warta-ip/pdf-file/2.wahyuntoipvol-15.pdf 